\title{
Gender, Utopias and the Savage Slot: The Role of Anthropology in the (De)Construction of a Concept
}

\author{
Irene Peano \\ ORCID: https://orcid.org/0000-0002-7085-0911 \\ (University of Lisbon, irene.peano@gmail.com)
}

\section{The Gender Wars: Recursive Otherings ${ }^{1}$}

During the last decade, a reactionary discourse against what has been named 'gender feminism' in the English language, 'théorie du genre (or gender)' in French and 'ideologia (or teoria) gender' in Italian found its way into the mainstream in many parts of the world. This global, catholic-led crusade, however, has a longer history. It first coalesced into an opposition front with strongholds in the United States in the mid1990s, against the employment of the concept of 'gender' in the proceedings of several UN International Women's Conferences. Subsequently, the movement gained increasing traction among a range of subjects and groups, across different European countries and beyond, spearheaded by the Vatican and by other powerful catholic lobbies such as Opus Dei, but also animated by non-confessional far-right groups. From the inception, it set out to oppose visions of womanhood (and their concurrent policies) which do not reduce it to compulsory motherhood, nurturing roles and heterosexual marriage, as well as decrying policies against the discrimination of homosexuality, such as education initiatives, the legalisation of same-sex marriage and of child adoption. ${ }^{2}$

\footnotetext{
1 Research for this article was carried out under the aegis of the ERC Project 'The Colour of Labour: The Racialized Lives of Migrants (COLOUR)', Advanced Grant no 695573 - PI Cristiana Bastos.

2 For meticulous reconstructions of the trajectory of this conflict, see for example Fillod (2014), referring most specifically to the French context; Garbagnoli $(2014,2016)$ for a more comparative approach considering both the French and the Italian cases; Dall'Orto (2016) on the Italian context; Baden and Goetz (1997) for an account of the debates before and during the Beijing UN conference; Kováts and Põim (2015) for a multi-country collection of essays focusing most prominently on the Eastern European front, as well as on France and Germany; Kuhar and Paternotte (2017) for crossEuropean case studies. Although the debate is indeed a global one, for reasons of space and due to the European focus of my research, throughout this text I am restricting my sources to a few cases drawn mainly from such context. Lastly, whilst what I am calling 'the gender wars' might have acquired specific shapes in the last two decades, of course their underlying ideological conflict is much older, dating back at least to the beginnings of second-wave feminism and thus to the very
} 
In short, 'gender' as a 'theory' or 'ideology' is here made to stand in for the (avowedly unwarranted) questioning of a natural, divinely ordained, immutable state of affairs, in which male and female are supposed to be self-evident in their relations and definitions. This order, according to anti-gender campaigners, must result into uniform, heterosexual, reproductive, familistic roles. Gender, therefore, is understood as only a fictive name for (binary) sex, one which gives the false impression that nature can be bent at will.

Significantly, to promote homophobic and misogynistic positions, across many countries this set of campaigns employs the term gender in its English version, despite equivalents in several languages being of common use, at least in academic and feminist circles. Such choice extends the reach of what Judith Butler (defined by the anti-gender zealots as 'the she-pope of gender feminism') identified as 'a disturbing co-optation of anti-imperialist discourse' $(2004,186-7)$ by the Vatican's top echelons, in conjunction with different state apparatuses and ultra-conservative political organisations. For Butler, this manoeuvre aims 'to suggest that gender was an import from decadent strains within Western feminism, one imposed on "Third-World countries," often used interchangeably with the term "developing countries"' (Ibid.). More generally, as it manifests also in European contexts, it is supposed to show the foreignness of gender ideology to what lies outside the anglophone North Atlantic and all its derivations. An evidently disingenuous rhetoric (witness the opposition led by the same actors against 'gender feminism' in core North Atlantic contexts themselves), it would perhaps be more aptly labelled as a chauvinistic discourse.

In any case, the instrumental role assigned to 'the Third World' and its permutations is central to the gender wars in more ways than one, whilst hardly acknowledged in many cases. It is on this role, its genealogies and implications, that I want to focus. For gender as a concept arguably developed out of a concern with the control of perceived difference cum otherness, if with multiple and even conflicting agendas in mind and through a range of strategies. First elaborated by a range of scientific and medical interventions (from anatomy and gynaecology to clinical psychology) in the early to mid- $20^{\text {th }}$ century, to deal with intersex and transsexual subjects, it was then appropriated by much second-wave feminist theory and struggle, and finally incorporated into mainstream governmental projects (Repo 2015).

Thus, the early uses of the notion of gender applied to the management of bodies and psyches that did not conform to a binary order. Although they seemingly limited themselves to considering otherness as it emerged within 'Western' boundaries, what lay outside those boundaries can be shown to have played a central role in this genealogy. Likewise, as I will argue, such exotic otherness was crucial to second-wave feminist reflections. In the present context, 'the Third World' has come to occupy the position of that Other in multiple guises. Not only is it the domain of implementation of 'gender and development' projects (Baden and Goetz 1997), where 'gender equality' or the status of 
women are treated as development indexes; also in anti-gender chauvinist campaigns, such otherness is alternatively singled out as an exemplary of virtue or vice, innocence or sin.

I am particularly interested in exploring the (little analysed) contribution of anthropology, both as a discipline and more generally as a discursive trope, to the emergence of gender as a category of thought and practice. Anthropological research, after all, was carved out as a specialised technique for the construction, and even the control, of Otherness. As Rolph Trouillot (2003) showed, in the $19^{\text {th }}$ century the institutionalisation of the discipline developed out of a trajectory that had been set in motion several centuries before - at the very moment, the Renaissance, in which Christendom could turn to the Atlantic and thus become 'the West'. What matters most in Trouillot's argument for the purposes of my own is that the domain anthropology would be called to study, which he defined 'the Savage slot', was contained within a wider Utopian projection, an imaginary that aimed at an ideal ordering. Whether by analogy or opposition, the savage slot fed these visions of perfect harmony and control that manifested in a number of genres and forms. Utopia, in turn, was driven by a search for order which arguably inspired the elaboration, as much as the critique, of gender as a concept, and thus also permeates the gender wars. In this domain, anthropology has often served as the instrument, and sometimes as the name, for recursive operations of othering that shaped different utopian forms.

\subsection{Against gender: Conflicts anthropologies}

Significantly, both Pope Benedict XVI and Pope Francis, as well as other Vatican institutions, catholic fundamentalists, conservative politicians and intellectuals, in attacking 'gender ideology' and 'de facto unions' (of same-sex or heterosexual unmarried couples) have made explicit references to 'anthropology'. On the one hand, through this gloss they identify apparatuses of subject formation developing in the contemporary world, such as 'the individualist anthropology of radical neo-liberalism', 'an overall and systematic calling into question of traditional moral doctrine, on the basis of certain anthropological and ethical presuppositions', 'a pessimistic anthropological vision that destructures and breaks down subjectivity,', an 'anthropological revolution' that questions the very foundations of humanity, ${ }^{4}$ indeed an 'anthropological emergency' (Garbagnoli 2017). In this sense, they are employing anthropology as the other of theology, a human creation of values which departs from the divine order - negating, and thus negatively reaffirming, godly utopia.

3 Pontifical Council for the Family (2000). Family, marriage and "de facto" unions, http://www. vatican.va/roman_curia/pontifical_councils/family/documents/rc_pc family_doc_20001109 defacto-unions en.html\# ftnref8; seealso the Final report of the Bishops'Synod to Pope Francis (2015), https://press.vatican.va/content/salastampa/it/bollettino/pubblico/2015/10/24/0816/01825. html

4 Address of his holiness Benedict XVI on the occasion of Christmas greetings to the Roman curia, Clementine Hall (Friday, 21 December 2012), http://w2.vatican.va/content/benedict-xvi/en/ speeches/2012/december/documents/hf_ben-xvi_spe_20121221_auguri-curia.html 
At the same time, and in the same breath, they also refer to 'the anthropological and theological foundation' of the family and of marriage, 'the irreplaceable character of some anthropological principles regarding the man-woman relationship, which are fundamental for human cohabitation', a 'correct anthropological vision', 'the anthropological truth about the human love between a man and a woman', 'the human anthropology supported by the Church' (de Coles 2006, 624-641), a 'theological anthropology' (Case 2016) postulating the complementarity of the sexes, the anthropological structure of human beings (Peeters 2013), synonymous with 'human nature' (Garbagnoli 2017).

Here, anthropology seems to be elevated to the ranks of a utopia itself, cloaked in the authoritative mantle of science. A trained reader cannot help but hearing echoes of alliance theories of kinship and marriage, first proposed by French anthropologist Claude Lévi-Strauss (1949). Indeed, his ideas about the incest taboo in connection to the exchange of women through exogamous marriage, as universally foundational to human culture, have constituted one of the reference points for debates over the structure of gender relations, in both feminist and fundamentalist circles (cf. Fassin 2014). At the same time, recourse to the notion of anthropology in its Kantian sense, as the selfreflexive understanding of the human condition, entails a much deeper genealogy - one which indeed originated in Christendom via the latter's authorised representatives, and in which the noble savage and the barbarian became the (implicit or explicit) meters against which to assess the nature of being, and particularly of humanity (Beckett 2013).

Finally, articulating to both previous connotations, anthropology in these discourses also stands in for the classical organisation of knowledge about the savage slot:

In other places, cohabitation (for more or less extended periods of time) is frequent until the conception or birth of the first child. These customs correspond to ancestral and traditional practices which are very strong in some regions of Africa and Asia and are related to the so-called "marriage by stages." These practices are in contrast with human dignity, difficult to uproot, and create a negative moral situation with a characteristic and welldefined social problem. This kind of union should not be identified with the de facto unions we are concerned with here (which are formed on the margin of a traditional kind of cultural anthropology), and pose a challenge for the inculturation of the faith in the Third Millennium of the Christian era. ${ }^{6}$

Thus, whether as a challenge to or a confirmation of the true Christian order of two immutable and complementary sexes, whose union must be sanctified in marriage, neofundamentalist ideology deploys anthropology in a series of recursive otherings (mangod, real-ideal, good-bad, the West and the rest, modernity-tradition, here-elsewhere). In this camp, a contradictory political rhetoric on the sexual order of things intersects (and at times clashes) with racialising operations, delineating multiple alliances and

5 See fn. 2. above.

6 Pontifical council for the family 2000. Family, marriage and "de facto" unions, see fn. 2, emphasis mine. 
alternating strategies (Fassin 2014).

Explicitly referenced or tacitly implied, the savage slot lurks behind neofundamentalists' tirades against the wrong sorts of human behaviour. In this sense, however, the reactionary crusade against 'gender' may be seen to share with (at least some of) its adversaries more than either would likely be prepared to admit. By tracing the genealogy of gender as a concept, similar operations of utopian othering can be identified. The notion, in fact, derived from the observation of practices which, across 'primitive' and 'civilised', 'traditional' and 'modern' contexts were seen to put into question the supposedly 'natural' order of binary heterosexual subjectivities. Yet, these uncanny correspondences remain unexplored by most feminist and queer scholarship, despite the fact that neither 'gender' as a concept nor anthropology as a discipline has been immune from critique and deconstruction.

\subsection{Un/doing gender, sexual difference and their biopolitics}

If the conservative reaction and its underlying logics come perhaps as no surprise, the notion of gender and gender theory do not hold an unproblematic status in the opposing camp, either - as Butler herself (2004), among many others, has noted. Controversies can become evident by examining the discordant responses to reactionary attacks: diverging rebuttals have made older debates among scholars and/as activists surface once again.

For many critics, the neo-fundamentalist discourse against gender constitutes a total mystification of what the notion has come to represent, both for feminist politics in general and for its academic branches in particular (cf. Garbagnoli 2014, 2016; Dall'Orto 2016; Fillod 2014; Marzano 2015). To claim that gender feminists' supposed 'theory' considers identity as a matter of individual choice, that it pushes children to homosexual behaviour and to precocious sexual experiences, as anti-gender campaigners claim, amounts to a full-blown conspiracy theory which constructs a 'straw man' to spread unjustified terror. This position can be subsumed, for the sake of simplicity, under a social-constructivist gloss, which defines gender as the set of socio-cultural attributes ascribed to biologically (thus also 'naturally') different bodies ('sexes') - male and female, with the addition of intersexuals as exception. Here, the historical, geographical, cultural variations of gender do signal a degree of potential malleability towards more inclusive and egalitarian arrangements, but, however slippery, the boundary between 'nature' and 'culture' remains foundational. Like neofundamentalists, in some instances socialconstructivist feminists and LGBT activists appeal to nature and science to support their claims (cf. Bellè, Peroni, \& Rapetti 2016), making of diversity alternatively the norm or its deviation but never questioning the paradigm which engenders such dichotomies.

For others, on the contrary, it is necessary to assume as one's own what the enemy is attributing them/us, namely the active deconstruction of sexual difference and its naturalness, which cultural constructivism does not address, becoming guilty of 'negationism' and thus of the perpetuation of a heterosexist order (Ardilli \& Zappino 
2015; Zappino 2016a,b,c). This represents one radical strand of queer theory. Yet others, among whom Butler herself, advocate a more cautious assessment of the unstable, contested status of sexual difference and gender in contemporary public culture, and as a hallmark of modernity, towards the critique of heteronormativity and sexism, rather than in support of an alternative norm (Bernini 2016). Despite their differences, here the question of othering is addressed in terms of a critique of its epistemological foundations: the inert base which gender coustructionists take for granted, the naturalness of sex, is problematised as the product of a specific order of power/knowledge, that same order which posits otherness in universalistic terms as a tool for domination and control.

Difference feminists and their allies, for their part, adopt a diametrically opposed viewpoint, defending the constitutive duality of a male-female polarity, if on premises incompatible with those of the reactionary counterpart. However, they reach partly overlapping conclusions by expressing scepticism against what they see as the propagation of messages derived from queer thought and its purported deconstruction of sexual difference (Muraro 2004, 2015). It is in this camp (and partly in that of social constructionists), that echoes of the savage slot and their racialising operations resonate most clearly. Once again, Butler (2004, chap. 5) brought the matter up for analysis, citing an editorial appeared in French daily Le Monde, signed by philosopher Sylvaine Agacinski, in which the latter, drawing on structuralist premises, resuscitates the notion of a "symbolic law" to argue that homosexuals should not form families. Here, again, the spectre of 'Americanisation' is agitated to decry unsavoury changes.

[T]he incest taboo functions in Lévi-Strauss not only to secure the exogamous reproduction of children but also to maintain a unity to the "clan" through compulsory exogamy, as it is articulated through compulsory heterosexuality. The woman from elsewhere makes sure that the men from here will reproduce their own kind. She secures the reproduction of cultural identity in this way. The ambiguous "clan" designates a "primitive" group for Lévi-Strauss in 1949, but it comes to function ideologically for the cultural unity of the nation in 1999-2000, in the context of a Europe beset with opening borders and new immigrants. The incest taboo thus comes to function in tandem with a racialist project to reproduce culture and, in the French context, to reproduce the implicit identification of French culture with universality (...). The incest taboo might be seen as working in conjunction with the taboo against miscegenation, especially in the contemporary French context, insofar as the defence of culture that takes place through mandating the family as heterosexual is at once an extension of new forms of European racism (Butler 2004, 121-22).

Butler thus comes close to questioning the othering role of (classical) anthropological knowledge in addressing issues of gender, sexuality and kinship. Indeed, she dismisses the traditional notion of culture as a bounded, self-sufficient entity, the one that for Trouillot underlies the study of the savage slot, and relies extensively on contemporary anthropological scholarship to disprove the Lévi-Straussian take on issues of marriage and kinship. Yet, more complex problematisations need drawing, which will have to rely on the genealogical questioning of gender as a concept. 
Behind diverging opinions on how to respond to (or indeed redouble, but from a feminist position) the attacks against 'gender feminism/theory/ideology' lie different takes on the notion of gender itself. Indeed, Butler's stance openly bids to differ also from those, among whom some queer scholars as well as feminist theorists, that would like to get rid of the concept of gender altogether, thus, once again, finding themselves in the eerie company of Vatican clergy and their lay followers. For some queer studies scholars, gender, as the hallmark of feminist theory, must be disposed of and replaced by sexuality as the proper object of study, for gender would stand for a heteronormative order.

The Vatican seeks to undo gender in an effort to rehabilitate sex, but methodoriented queer theory seeks to undo gender in an effort to foreground sexuality. The Vatican fears the separation of sexuality from sex, for that introduces a notion of sexual practice that is not constrained by putatively natural reproductive ends. And in this sense it appears that the Vatican, in fearing gender, fears the separation of sexuality from sex, and so fears queer theory. Queer methodology, however, insists on sexuality, and even (...) on "sexuality and sex." Such understandings evacuate gender as well, but only because gender stands for feminism and its presumptive heterosexuality (Butler 2004, 184).

Others have critiqued the concept of gender on different grounds:

as a way to defuse the political dimension of feminism, in which gender becomes a merely discursive marking of masculine and feminine, (...) as ways to legitimate an academic domain by refusing to engage polemics against feminism, on the value of the overly sociological construal of the term. Gender is thus opposed in the name of sexual difference precisely because gender endorses a socially constructivist view of masculinity and femininity, displacing or devaluing the symbolic status of sexual difference and the political specificity of the feminine (ibid., 184-5).

Such would be the position of Braidotti (1994) and Grosz (1994), among others, but also of difference feminists inspired in various ways by the work of sexual-difference theorist Luce Irigaray (1985) - who herself may be seen to have relied on her own version of the savage slot in pitting 'eastern' or 'oriental' sexuality against the 'western' one.

As a matter of fact, the feminist controversy over gender is hardly new. The category has been far from a universally accepted analytic ever since the initial elaboration of second-wave feminist thought, as one of the latest critics of the term notes (Repo 2015, 75). However, until very recently most such critiques were based on ahistorical, albeit always politically inflected considerations. They failed to investigate gender genealogically and to trace the ideological and epistemological, political and economic framework within which the concept itself was elaborated. To correct such shortcomings, Repo's The biopolitics of gender provides a (rather cursory, yet important) genealogy of the concept, from its development in 1950s US clinical sexology, through its appropriation by a significant portion of feminist scholarship in the 1970s, up until its deployment in demographic and more generally public policy, most markedly from the 1980s onwards.

For Repo, as for Preciado before her (2013 [2008]), gender represents an apparatus 
of biopolitical governmentality, 'instrumental in sedimenting Western post-war capitalism through the management of sex' (2015, 2-3). Just like sexuality in the Victorian era, and building upon its discourse, gender became a critical nexus for population governance with the development of surgical, pharmaceutical and psycho-therapeutic devices to manage 'deviancy'. These techniques would then spread their range of applications to ever wider segments of the (global) population. After the traumatic discredit of scientific theories based wholly on biology, racism and eugenics, popular during the late $19^{\text {th }}$ and early $20^{\text {th }}$ centuries, post-war governance turned to social conditioning and behavioural science, still aided by biotechnological interventions.

The bodies that had become deployed by sexuality in the Victorian era were not keeping pace with accelerating technological and economic progress. Functionalism and behaviorism aimed to discipline the "now inefficient, maladaptive, obsolescent" biological bodies of industrialization and urbanization by "updat[ing] our biology through social control" (Haraway 1991, 35). As in the past, the production of new mechanisms of control premised on particular conceptions of normality was not based on the study of "normal" individuals. Rose $(1999,133)$ argues that normality is continually defined and redefined through knowledge produced around pathological, troublesome, or in some other way non-conformist children. Such is the case also in the birth of gender, which emerged through the problematization of the hermaphrodite child in the context of the postwar middle-class nuclear family (ibid., 29).

Extrapolating from Repo's account, 'hermaphrodites' (later to be reclassified as 'intersexuals'), as well as transsexuals, may be seen to play the role of the Other within the post-war Western order - itself a permutation of Utopia - of binary sex and heteronormative sexuality. It was precisely in an effort to 'normalise' these subjects, to make them conform to (and thus realise) a consumerist-capitalist project - which crucially relied also on individual liberation and self-realisation -, that the notion of gender emerged. The newly articulated distinction-in-the-making, between anatomy and psychology, 'sex' and 'gender', was meant to bend either one to match with the other. People whose self-perception did not meet what was expected of their anatomy, or whose anatomy itself may defy the canons of a binary sexual order, could be treated through surgery, hormonal therapy and psychological counselling, in various combinations according to circumstance, such that the utopian binary order would be artificially brought into being.

Like Preciado (whom shefails to quote), Repo reproaches many second-wave feminist theorists (but also queer theorists such as Butler) for their lack of acknowledgement of what she terms the biopolitical, governmental core of gender as a concept. For her, feminism itself thus represents a biopolitical project. Yet, both Repo and Preciado omit to take into account the crucial role that the 'Savage slot', the primitive utopia in all its variations, played in shaping the concept of gender, in its bio-medical as much as in its feminist versions. In both texts, some references to anthropology do appear, but oddly enough they do not warrant the drawing of a parallel between the intersex/transsexual and the savage, other than in passing. In this sense, they do not fully challenge the power/ 
knowledge bases of gender discourse.

Such omission is rather startling, given the ample treatment of the nexus between deviancy and savagery/primitiveness in the $19^{\text {th }}$ century discourse on sexuality (cf. McClintock 1995; Stoler 1995) - a discourse upon which, according to both scholars, gender governmentality built. Equally, alongside deviancy and neurosis, during the Victorian era another exemplar of biopolitical intervention in the sexual sphere, the child, had immediate correspondences in the savage, the primitive, the colonised. The latter were positioned onto a hypothetical ladder of progress that had them on the same level as 'civilised children' (Stocking 1986, 1987) and women. At the same time and in the same period, radical critiques of capitalist society looked at 'modern primitives' as vestiges of an idyllic time of matriarchy, or at least of equality between the sexes, before the invention of private property put a check upon women's sexual and political freedoms (e.g. Engels 1972 [1884]; cf. Di Leonardo 1991; Moore 1988). Whether noble or barbarian, savages were one of the foci of the incipient discourse on sexuality and its attendant (utopiandriven) biopolitics.

Whilst Preciado (2013) makes a passing (and imprecise) reference to the work of cultural anthropologist Margaret Mead as one of the first to allegedly introduce the notion of gender alongside much later work by Ann Oakley (106), s/he also cites an intersex activist who defines the sex-reassignment protocols for 'anomalous' anatomies as genital mutilation:

\begin{abstract}
Why didn't 1970s culturalist and constructivist feminists fight against clinical diagnosis, reassignment protocols for intersex bodies, normalizing biochemical and surgical technologies, and the binary regime within administrative systems? Intersex activist Cheryl Chase answers: "Intersexuals have had such difficulty generating mainstream feminist support not only because of the racist and colonialist frameworks that situate clitoridectomy as a practice foreign to proper subjects within the first world, but also because intersexuality undermines the stability of the category of 'woman'" (Preciado 2013, 106).
\end{abstract}

The ('racist and colonialist') tendency to categorically divide 'first' and 'third' world practices may indeed be a clue to understand also why Preciado her/himself did not consider the role of the 'savage slot' in developing gender governance. However, not only anthropology and its object were crucial in elaborating the notion of gender, but, by implication, 'the stability of the category of "woman"', and thus the social-constructivist paradigm, was undermined as much by savage figures as by Western subjects who defied the binary sexual order - a point reiterated by black and third-world feminists in the last four decades (e.g. Mohanty, Russo and Torres 1991).

Repo, for her part, expands her sources to include, aside from Mead herself, also Ruth Benedict and Franz Boas as three of the main figures that promoted the shift from a biologistic to a psycho-culturalist, constructivist approach in medical as much as in social science $(2015,53 ; 60)$. The influence of the founders of US cultural anthropology, as well as of other canonised figures in the discipline, such as Bronislaw Malinowski, considered 
as the father of British social anthropology, and the already cited champion of the French structuralist school, Claude Lévi-Strauss, on second-wave feminist thought is cited in passing in relation to the work of renowned theorists Kate Millett (79), Germaine Greer (84), Ann Oakley (85), Gayle Rubin (87-90) - herself an anthropologist -, Susan Kessler and Wendy McKenna (97).

And yet, whilst both Repo and Preciado mention critiques of the notion of gender for 'its perpetuation of mind/body dualism, biological foundationalism, heterosexism, and racial and cultural bias' (Repo 2015, 75), the central role of the 'savage slot' in both the creation and critique of the concept remains hidden.

\section{Gender, the Savage Slot and Anthropology: Concluding Notes for a Genealogy}

Clearly, what was variously defined as 'cross-cultural comparison' or as the analysis of different social arrangements played a central role in disputing the incontrovertibility of certain features of femininity and masculinity. Sexual practices, social roles and divisions of labour, modes of rearing, ideals and expectations, even some bodily capacities and physical differences - many of which with time came to be categorised under the rubric of 'gender' - were seen to be distributed among subjects in the savage slot according to arrangements that stood at odd angles with those of the bourgeois, capitalist social order. Thus, the savage slot gradually provided crucial evidence to separate sexual difference as a natural given (however much its exact boundaries were disputed from the start) from gender as a product of socialisation, establishing the social constructivist position on ever more solid grounds.

As we have seen, late-19 $9^{\text {th }}$ century critiques of capital had initiated this trend - at least in the sense that they were the oldest theories on which some (mainly Marxist/ socialist) second-wave feminists, among whom anthropologists doing research in socalled 'simple', 'egalitarian', hunter-gatherer/foraging or 'pre-capitalist societies', drew to argue their point (e.g. Leacock 1978, Sacks 1974; cf. Di Leonardo 1991; Moore 1988). The evidence they amassed was seen to demonstrate that women's subordination was not universal, but depended largely on the organisation of production and reproduction.

Yet, cultural and radical feminists, while rejecting biological explanations (which sometimes they attributed to early anthropologists themselves), would object to such conclusions and question the scientificness of its evidence. Instead, they sought to find cultural and/or social keys to explain what they often saw as the generalised hold of patriarchy across all contexts. Many relied on the conceptual toolkit provided by the work of mid- $20^{\text {th }}$ century clinical psychologists and by early $20^{\text {th }}$ century cultural and social anthropologists. The latter had criticised thinkers of the Victorian era (among whom Engels himself) for 'the search for a hypostatized past - especially the emphasis on unilinear evolution and the transition from "mother-right" to "father-right"' (Moore 
1988, 12). Furthermore, some of the emerging anthropological schools of the time, and especially the British functionalist and structural-functionalist ones, influenced theories that played a crucial role in US clinical psychology's development of the notion of gender.

Equally, the 'culture and personality' school that dominated US anthropology in the first half of the $20^{\text {th }}$ century anticipated the dismissal of purely biological theories by opposing a fierce critique based on social-scientific evidence. Whilst their main object of polemic was race, they (and especially the women, among whom Margaret Mead and Ruth Benedict) also questioned the meanings and attributes of what was labelled as simply 'sex'. Their own personal lives testified to a quest for sexual freedoms, fashionable at the time among the intellectual elites, which certainly influenced their studies (and vice-versa). At the same time, they were also public intellectuals whose writings had wide resonance outside academia (Di Leonardo 1998). Indeed, according to some contemporary writers, early US anthropologists came close to being 'queer modernists' (Banner 2003), whilst others have questioned their work for precisely the opposite reason, claiming that in the end it reinforced rigid ideals of what male and females should be like (Repo 2015, Di Leonardo 1998).

Whatever the case, early cultural and social anthropologists had provided conclusive evidence that what were generally known as 'sex roles' could acquire a number of traits at odds with those of Western culture, and were thus widely cited by feminist scholars in the 1970s. However, the latter did not necessarily perceive anthropology, or at any rate all anthropology, as a positive influence, or at least as a univocal one, for feminism. They saw the domain of knowledge reserved to anthropology as acting, alternatively, to reinforce or to challenge universals, either on 'cultural' or on 'natural' presuppositions, and thus to serve or to oppose the goals of feminism. Yet, across different theoretical positions within the second-wave feminist camp, 'savages' and their heirs were never absent, whether in communist theories, or through the perspective of early anthropologists' 'ethnographic liberalism' (Di Leonardo 1991; Trouillot 2003), one which stopped short of critiquing state forms and colonial projects, but which sought to give 'savages' legitimacy through scientific inquiry into the rationality and viability of each socio-cultural arrangement. Within the latter position, both challenges to and reinforcements of the natural order of sex were to be found.

In her influential book Sexual politics, Millett, the first feminist theorist to avowedly employ the notion of 'gender' in her writings (1970), spoke of the socialisation of individuals into patriarchal societies as restricted within the confines of the family. To explain how such containment could be enforced, she evoked the 'principle of legitimacy' elaborated by Malinowski $(1927,1962)$ :

...an insistence that "no child should be brought into the world without a man - and one man at that - assuming the role of sociological father". By this apparently consistent and universal prohibition (...) patriarchy decrees that the status of both child and mother is primarily or ultimately dependent upon the male (Millett 1970, 35). 
Millett also cited Mead to prove that male activities, whatever they are, are always given more prestige (something which somehow went against the grain of Mead's own arguments). More generally, she drew on an ample range of anthropological writings to demonstrate, on the one hand, the political expediency of patriarchal convictions about women and the universality of patriarchal institutions, but also, on the other, the role of the social sciences, including anthropology itself, in legitimating this order (cf. also Greer 1999 [1970]; Kessler and McKenna 1977). Despite her analysis of universal constants, Millett and many of her contemporaries, like early anthropologists, clearly adopted an evolutionary paradigm, dividing 'primitive' life, or 'society', from 'historical society', or 'preliterate' against 'civilised' groups. But, again like many $20^{\text {th }}$ century anthropologists and some of her contemporaries (such as Germaine Greer), she cast doubt on the transposability of 'contemporary primitiveness' onto the past to explain the origins of patriarchy. Yet, her vision of the world very much responded to categorical principles of otherness. She cited various forms of patriarchal 'cruelties and barbarities', which she catalogued according to an implicit scale and placed mostly in the domain of the savage slot:

the suttee [sic] execution in India, the crippling deformity of footbinding in China, the lifelong ignominy of the veil in Islam, or the widespread persecution of sequestration, the gynacium [sic], and purdah. Phenomenon such as clitoroidectomy [sic], clitoral incision, the sale and enslavement of women under one guise or another, involuntary and child marriages, concubinage and prostitution, still take place-the first in Africa, the latter in the Near and Far East, the last generally (Millet 1970, 46).

Kessler and McKenna (1977), whilst less tied to an evolutionary paradigm, are also among the most emblematic scholars in their use of anthropological evidence. They dedicated an entire chapter of their book to 'Cross-Cultural Perspectives on Gender' in which they cited a number of anthropological works on the figure of the berdache - a blanket term of European derivation used to index subjects variously described as 'neither man nor woman', 'homosexuals', 'half-woman, half-man', etc. These belonged to different Native American groups until their gradual disappearance in the first half of the $20^{\text {th }}$ century. Against what they saw as skewed anthropological interpretations, which assumed an immutable, binary biological core to identities that Kessler and McKenna resignified in terms of gender, berdaches in their analysis should be defined as a third gender, thus defying the universality of a binary order. Their recourse to evidence from other cultures was clearly explained in terms of the need to question the naturalness of gender arrangements. Furthermore, in such quest they believed it methodologically expedient to study 'how exceptions are accommodated' to 'best understand the nonexceptional cases' (cf., 23). Once again, recursive otherings emerge at the core of the elaboration of gender as a concept.

Equally extensive use of evidence from anthropology was made by Ann Oakley (1972, esp. chs. 2 and 4), who cited dozens of case studies from across the world: 
to distinguish more clearly between the biological and cultural causes of sex differences, we must look beyond our own society. How do other cultures define personality differences by sex? Do they make a distinction between male and female, and if so do they make the same distinctions as Western culture does? (Oakley 1972, 52-4).

Like many other authors, Oakley looks at the elsewhere as much as, and analogously to, the past, again implicitly adopting an evolutionary framework.

Yet, towards the end of the 1970s, the constructivist paradigm began to be contested by anthropological research itself, and by post-structuralist thinkers such as Michel Foucault (1981). These scholarly developments went hand-in-hand, and were indeed influenced by, an increasingly vocal anti-racist and anti-imperialist critique which did not spare feminism itself, accused of modelling its vision upon the subjectivity of white, middle-class women. This was the milieu in which what became to be known as queer theory would eventually develop. Anthropological writings indeed started to question the universality and foundationalism of notions of 'nature' and 'sex', and works such as Carol MacCormack and Marilyn Strathern's edited volume Nature, Culture, Gender (1981) are cited by Butler in her seminal Gender Trouble (1990) precisely on those grounds. Yet, such early critiques do not move beyond 'ethnographic liberalism' and thus reproduce the savage slot.

The extent to which queer theory, and indeed anthropology, have managed to 'claim the specificity of otherness' (Trouillot 2003,27), i.e. to overcome the categorical othering of the savage slot, remains contested into the present. If certainly the deconstruction of sex is taken for granted in much contemporary scholarship, constructivist strands are by no means superseded and have inflected public policy and governmental projects. At the same time, claims to some forms of universality maintain a residual appeal even for radical thinkers such as Butler, who, as we have seen, has equally missed the savage face in deconstructing gender - and largely ignored the biopolitical implications of gender within contemporary processes of value extraction and profit-making. A thorough questioning of the role of institutionalised anthropology and its knowledge production on the savage slot in relation to gender might, thus, give some promising renewed energy towards those ends.

\section{Literature}

Baden S. \& A.-M. Goetz 1997. "Who Needs [Sex] When You Can Have [Gender]?” Feminist Review 56:3-25.

Banner L. 2003. Intertwined Lives: Margaret Mead, Ruth Benedict, and Their Circle. New York: Vintage. 
Beckett G. 2013. "Thinking with Others: Savage Thoughts about Anthropology and the West." Small Axe 42:166-181.

Bellè E., C. PeronI, \& E. Rapetti 2016. "La natura del gender: Il conflitto sulla cittadinanza sessuale, tra dicotomie e ambivalenze". In F. Zappino (Ed.), Il genere tra neoliberismo e neofondamentalismo. Verona: Ombre Corte.

Bernini L. 2016. “La »teoria del gender«, i »negazionisti« e la »fine della differenza sessuale«."About Gender 5(10):367-81.

Braidotti R. 1994. Nomadic Subjects: Embodiment and Sexual Difference in Contemporary Feminist Theory. New York: Columbia University Press.

Butler J. 1990. Gender Trouble: Feminism and the Subversion of Identity. New York: Routledge.

Butler J. 2004. Undoing Gender. London-New York: Routledge.

Case M. A. 2016. "The Role of the Popes in the Invention of Complementarity and the Anathematization of Gender." Religion and Gender 6(2):155-72.

Dall'Orto G. 2016. "I turbamenti del giovane Gender." H-ermes. Journal of Communication 7:33-60.

Di Leonardo M. 1991. “Gender, Culture and Political Economy: Feminist Anthropology in Historical Perspective." In M. Di Leonardo (Ed.), Gender at the Crossroads of Knowledge: Feminist Anthropology in the Postmodern Era. Berkeley: University of California Press.

Di Leonardo M. 1998. Exotics at Home: Anthropologies, Others, American Modernities. Chicago: University of Chicago Press.

Engels F. $1972\left(1884^{1}\right)$. The Origin of the Family, Private Property, and the State. New York: Pathfinder Press.

Fassin E. 2014. "Same-Sex Marriage, Nation, and Race: French Political Logics and Rhetorics." Contemporary French Civilization 39(3):281-301.

Fillod 0. 2014. "L'invention de la »théorie du genre«: le mariage blanc du Vatican et de la science." Contemporary French Civilization 39(3):321-33.

Foucault M. 1981. The History of Sexuality, Vol. 1: The Will to Knowledge. Harmondsworth: Penguin.

Garbagnoli S. 2014. „»L'ideologia del genere«: L'irresistibile ascesa di un'ivenzione retorica vaticana contro la denaturalizzazione dell'ordine sessuale". About Gender 3(6):250-63.

Garbagnoli S. 2016. “Against the Heresy of Immanence: Vatican's 'Gender' as a New Rhetorical Device Against the Denaturalization of the Sexual Order." Religion and Gender 6(2):187-204.

Garbagnoli S. 2017. "Italy as a Lighthouse: Anti-Gender Protests between the »Anthropological Question« and National Identity." In R. Kuhar \& D. Paternotte (Eds.), Anti-Gender Campaigns in Europe: Mobilizing against Equality. London: Rowman and Littlefield 
Greer G. 1999. The Female Eunuch. London: Flamingo.

Grosz E. 1994. Volatile Bodies: Toward a Corporeal Feminism. Bloomington: Indiana University Press.

Irigaray L. 1985. Speculum of the Other Woman. Ithaca: Cornell University Press.

Kessler S. \& McKenna W. 1977. Gender: An Ethnomethodological Approach. Chicago: University of Chicago Press.

Kováts E. \& Põim M. (Eds.) 2015. Gender as Symbolic Glue: The Position and Role of Conservative and Far Right Parties in the Anti-gender Mobilizations in Europe. Foundation for European Progressive Studies, http://library.fes.de/pdf-files/ bueros/budapest/11382.pdf.

Kuhar R. \& D. Paternotte (Eds.) 2017. Anti-Gender Campaigns in Europe: Mobilizing Against Equality. London: Rowman and Littlefield

Leacock E. 1978. “Women's Status in Egalitarian Society: Implications for Social Evolution." Current Anthropology 19(2):247-75.

Lévi-Strauss C. 1949. The Elementary Structures of Kinship. Boston: Taviston.

Marzano M. 2015. Papà, mamma e gender. Rome: UTET.

Malinowski B. 1927. Sex and Repression in Savage Society. London: Humanities.

Malinowski B. 1962. Sex, Culture and Myth. New York: Harcourt.

McClintock A. 1995. Imperial Leather: Race, Gender and Sexuality in the Colonial Contest. New York: Routledge.

McCormack C. \& Strathern M. (Eds.) 1980. Nature, Culture and Gender. Cambridge: Cambridge University Press.

Millett K. 1970. Sexual Politics. Chicago: University of Illinois Press.

Mohanty C., Russo A., \& Torres L. (Eds.) 1991. Third World Women and the Politics of Feminism. Bloomington: Indiana University Press.

Moore H. 1988. Feminism and Anthropology. Minneapolis: University of Minnesota Press. Muraro L. 2004. "Se il Cardinale Ratzinger fosse un mio studente." Il Manifesto, 7 August. Muraro L. 2015. “La differenza sessuale c'è. È dentro di noi." La Ventisettesima Ora, $28^{\text {th }}$ March, http://27esimaora.corriere.it/articolo/la-differenza-sessuale-ce-e-dentrodi-noi/

Oakley A. 1972. Sex, Gender and Society. London: Temple Smith.

Peeters M. A. 2013. Le gender, une norme mondiale? Tours: MamE.

Preciado B. 2013. Testo Junkie: Sex, Drugs, and Biopolitics in the Pharmacopornographic Era. New York: Feminist Press.

Repo J. 2015. The Biopolitics of Gender. Oxford: Oxford University Press.

Sacks K. 1974. "Engels Revisited: Women, the Organization of Production, and Private Property." In M. Rosaldo \& L. Lamphere (Eds.), Woman, Culture and Society. Stanford: Stanford University Press (207-22). 
Stocking G. 1986. "Anthropology and the Science of the Irrational: Malinowski's Encounter with Freudian Psychoanalysis", in G. Stocking (Ed.), Malinowski, Rivers, Benedict and Others: Essays on Culture and Personality. History of Anthropology, Vol. 4. Madison: University of Wisconsin Press.

Stocking G. 1987. Victorian Anthropology. New York: Free Press.

Stoler A.-L. 1995. Race and the Education of Desire: Foucault's History of Sexuality and the Colonial Order of Things. Durham: Duke University Press.

Trouillot M.-R. 2003. Global Transformations: Anthropology and the Modern World. New York: Palgrave MacMillan.

Zappino F. \& Ardilli D. 2015. "La volontà di negare: La teoria del gender e il panico eterosessuale." Il Lavoro Culturale, 14 July, http://www.lavoroculturale.org/lavolonta-di-negare/.

Zappino F. 2016a. "La sfida della teoria del gender: Eliminare i presupposti dell'omolesbo-transfobia." L'Indice dei Libri del Mese, 3 February 2016, http://www. lindiceonline.com/osservatorio/cultura-esocieta/la-sfida-della-teoria-gendereliminare-presupposti-dellomo-lesbo-trans-fobia/

Zappino F. 2016b. "Fine della differenza sessuale?" Paper presented at the seminar Fine della differenza sessuale?, organised by Lìbrati. Libreria delle Donne, Padua, 16 April.

Zappino F. 2016c. "Sovversione dell'eterosessualità". Paper presented at the seminar $A$ proposito di gender. Modelli familiari, ideologie, diritti, organised by Palazzo Ducale - Fondazione per la Cultura (Genoa) and by the editorial board of the journal About Gender. Rivista internazionale di studi di genere. http://effimera.org/ sovversione-delleterosessualita-federico-zappino/ 


$$
\text { Irene Peano (Lisbon) }
$$

\title{
Gender, Utopias and the Savage Slot:
} The Role of Anthropology in the (De)Construction of a Concept

\begin{abstract}
The paper addresses some of the ways in which anthropology, as a discourse and a discipline, has contributed to the forging as much as of the problematisation of the concept of gender, not only within the feminist, queer and LGBTQI camps, but also among Catholic fundamentalists. It argues that, despite some recent genealogical critiques of the concept of gender and its origins in mid- $20^{\text {th }}$ century bio-medical governance, insufficient attention has been paid to the role of the so-called 'savage slot' - as Rolph Trouillot defined the domain of knowledge carved out for anthropology, in a wider scheme of thought that has its origins at the same time as 'the West' became a reality. A more thorough genealogy of the ways in which anthropological thinking and evidence contributed to the construction, and then the deconstruction, of gender, can provide fruitful tools for a deeper challenge of the apparatus of gender itself.
\end{abstract}

Keywords: gender; anthropology; genealogy; racism; neo-fundamentalism; feminism.

Ethics in Progress (ISSN 2084-9257). Vol. 10 (2019). No. 1, Art. \#9, pp. 112-128.

Creative Commons BY-SA 4.0

Doi:10.14746/eip.2019.1.9 